\title{
Observed warming in cold anticyclones
}

\author{
Patrick J. M ichaels ${ }^{1, *}$, Paul C. Knappenberger², Robert C. Balling J r ${ }^{3}$, Robert E. Davis² \\ ${ }^{1}$ C ato Institute, Washington, DC 20001, USA \\ ${ }^{2}$ Department of Environmental Sciences, University of Virginia, C harlottesville, Virginia 22903, USA \\ ${ }^{3}$ Office of Climatology, A rizona State University, Tempe, Arizona 85287, USA
}

\begin{abstract}
During the past half-century, we find that the observed surface warming trend in the northern hemisphere, averaged across grid cells that contain at least $90 \%$ of the total monthly data, has been $0.051^{\circ} \mathrm{C}$ decade $^{-1}$. On a seasonally weighted basis, a relatively small area $(12.8 \%)$ contributed over half of the annual warming, and in the winter $26 \%$ of the area accounts for $78 \%$ of the warming. Our analysis demonstrates that this warming is almost exclusively confined to the dry, cold, anticyclones of Siberia and northwestern N orth America. The consequences of this type of regional warming are different than those associated with other regional warming scenarios. The spatial pattern of observed warming is not coincident with that projected by many of the leading general circulation models, including those featured in the 1996 Report of the Intergovernmental Panel on Climate Change.
\end{abstract}

KEY WORDS: Climate change - Regional temperature trends · Anticyclones

\section{INTRODUCTION}

In Climate Change 1995: The Science of Climate Change, the Intergovernmental Panel on Climate Change (Houghton et al. 1996, p. 4) states that 'The balance of evidence suggests a discernible human influence on global climate.' Most students of global climate change would argue that the consequences of climate change are potentially more dependent on its seasonal and spatial distribution than on the magnitude of a global average climate change. For instance, recent studies have shown that, while there has been little global temperature change for as much as 9 centuries prior to this one ( ones et al. 1998, Mann et al. 1999), significant regional anomalies such as the M edieval Warm Period and the Little Ice Age have had demonstrable social and economic impacts.

While global surface temperatures during the last half of the twentieth century have risen, the observations show that the rise has not been uniform, but instead has been marked by strong seasonal and regional warming trends (Balling et al. 1998). The most

*E-mail: pmichael@cato.org dominant pattern of change has been the large amount of warming that has occurred in the cold half of the year over much of central and northern Asia and in northwestern N orth America. Patterns of temperature change are more diffuse during other seasons and in other regions.

The pattern of temperature change is not inconsistent with an increasing atmospheric concentration of greenhouse gases (primarily, carbon dioxide). An increase in the atmospheric concentration of carbon dioxide is thought to warm the surface through both direct and indirect mechanisms (e.g. Ramanathan 1981). The surface is heated directly by the increase in downwelling infrared (IR) radiation emitted by the enhanced concentrations of trace gases. The troposphere is heated directly through the increased absorption of surface and cloud radiation, and, in turn, the warmer troposphere adds to the warming of the surface. There is also another process at work - water vapor feedback. As the surface warms, evaporation (latent heat transfer to the atmosphere) increases. The resulting increase in absolute humidity and atmospheric emissivity increases IR radiant emission from the troposphere, which further enhances surface warming and completes the positive feedback loop. 
The heating from water vapor feedback is thought to be many times that resulting from direct carbon dioxide emissions (e.g. Ramanathan et al. 1979, Ramanathan 1981).

These processes do not occur in a uniform strength across the entire globe; instead, local influences can act to determine both the relative and absolute magnitude of each. The direct contribution of carbon dioxide to the total emissivity of the atmosphere is greatest when the atmospheric water content is the least. As the specific humidity of the air increases, the overlap in IR radiant emittance between carbon dioxide and water vapor increases as well, effectively reducing the overall contribution of carbon dioxide to the total atmospheric emissivity (Staley \& J urica 1970, 1972). Also, in these dry locations, the lack of moisture means that more of the increased downwelling radiation is partitioned into sensible rather than latent heating (Houghton et al. 1996). Therefore, those regions with the lowest absolute humidity should show the greatest direct response to an increase in the atmospheric concentration of carbon dioxide.

The atmospheric emissivity due to water vapor alone increases logarithmically with the water vapor content (Staley \& J urica 1970, 1972). Using a simple model atmosphere with linear temperature and dew-point temperature, Staley \& J urica (1972) calculated the impact of water vapor on changing emissivity. For example, given an initial vapor pressure of $1.27 \mathrm{hPa}$ (a surface dew-point temperature of $-20^{\circ} \mathrm{C}$ ), a $1 \mathrm{hPa}$ vapor pressure increase raises emissivity by $6 \%$. By comparison, the same $1 \mathrm{hPa}$ vapor pressure rise starting from an initial vapor pressure of $23.67 \mathrm{hPa}$ (a surface dew-point temperature of $20^{\circ} \mathrm{C}$ ) increases emissivity by only $0.7 \%$. This shows that the addition of water vapor to the atmosphere causes the greatest increases in emissivity in very dry locations and thus should invoke the greatest temperature response there.

Therefore, as a result of both direct radiational effects and indirect water vapor feedback effects, a warming from the atmospheric build-up of carbon dioxide should be most prominent in air masses that are generally devoid of water. Further, if these air masses are largely decoupled from the global circulation for substantial periods of time, local processes should dominate, and the lack of mixing should make the warming especially obvious.

We hypothesize that the air masses that obtain these characteristics more than any others are the shallow, cold-core anticyclones of Siberian and N orth American winter. Especially in Siberia, these air masses remain 'decoupled' from the general circulation because of their inverted temperature structure, the weakening of cold-core anticyclones with height, and the physical constraints of the Siberian basin, where the physical geography allows for substantial pooling of cold, dense air.

This study examines the relative amount of warming in these air masses compared to the overall hemispheric changes. We hypothesize that the observed warming is especially confined to cold, dry air masses, and that the magnitude of the warming is proportional to the amount of dry air within these air masses.

\section{DATA}

To investigate this question, we incorporated 2 data sets into our analysis: the $5^{\circ}$ latitude by $5^{\circ}$ longitude gridded temperature history from the IPCC (Houghton et al. 1996), and the northern hemisphere monthly sealevel pressure and dew-point temperature climatology developed by J enne (1974) and obtained from the US National Center for A tmospheric Research (NCAR).

The IPCC data set is a combination of land surface air temperature data (J ones 1994) and oceanic temperature data (Folland \& Parker 1995). Although this temperature record extends back to the mid-nineteenth century, the data availability in the early part of the record is extremely limited. We chose to begin our analysis in 1946. This is near the beginning of the period during which the spatial coverage has been relatively constant and near present levels, although there is some decline in station number in recent years. According to the 1996 IPCC comprehensive report (Houghton et al. 1996), approximately two-thirds of the change in total radiative forcing from human activities has been since World War II. Data from the southern hemisphere are largely absent south of $45^{\circ} \mathrm{S}-$ a region that includes the primary regions of cold anticyclone formation in that hemisphere. In this study, therefore, we confine our analysis to the northern hemisphere.

The NCAR data set contains the climatological monthly average sea-level pressure and surface dewpoint temperatures (among a variety of other parameters) for $5^{\circ}$ latitude by $5^{\circ}$ longitude grid cells over the northern hemisphere for the period 1950 to 1964 derived from radiosonde records. Despite the age of these records, the climatologies are thought to be quite robust.

\section{RESULTS}

For each calendar year, and for each $5^{\circ}$ latitude by $5^{\circ}$ longitude grid cell with $90 \%$ complete data over the period 1946 to 1995, the mean 'winter' (cold half-year: October through March) and mean 'summer' (warm half-year: April through September) temperature ano- 

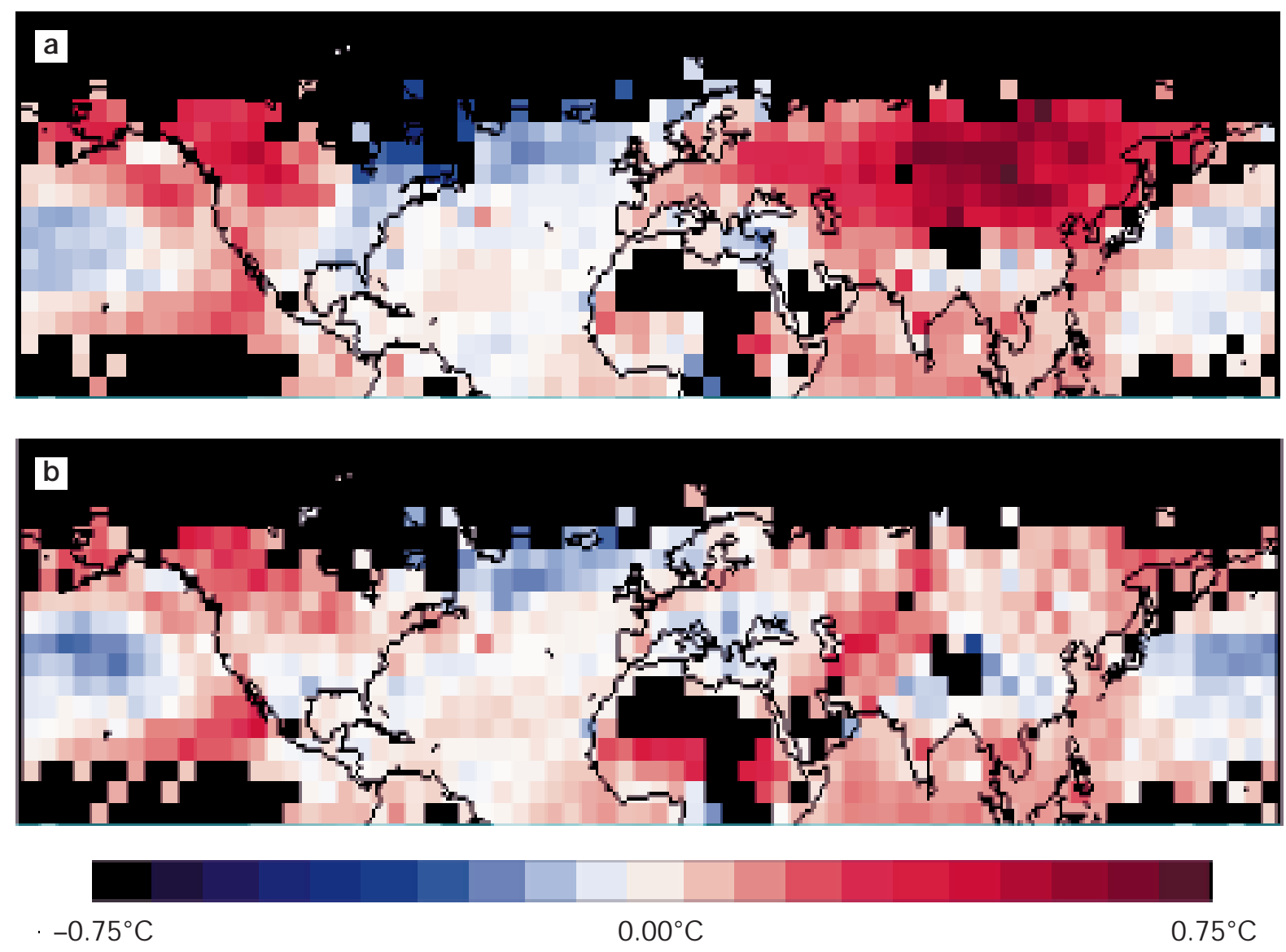

Fig. 1. (a) Winter season (October-M arch) and (b) summer season (A pril-September) temperature trends, $1946-1995\left({ }^{\circ} \mathrm{C}\right.$ decade ${ }^{-1}$ )

malies are determined. A least-squares regression line, representing the temperature change $\left({ }^{\circ} \mathrm{C}\right.$ decade $\left.^{-1}\right)$, is then fit through the seasonal time series in each grid cell.

The winter warming (Fig. 1a) is primarily confined to Siberia and northwestern North America. We have presented this chart in an earlier publication (Balling et al. 1998) but include it here to serve as a background for subsequent results. The net trend in overall winter warming over the coverage area (weighted by grid cell area) is $0.071^{\circ} \mathrm{C}$ decade $^{-1}$. Summer patterns (Fig. Ib) are more diffuse, with a net mean trend of 0.032 decade $^{-1}$. Combining the 2 seasons produces an annual net trend of $0.051^{\circ} \mathrm{C}$ decade ${ }^{-1}$. The winter-to-summer warming ratio in the last half of the twentieth century is 2.2 to 1 . The marked difference in the seasonal trends provides initial evidence in support of our hypothesis.

To investigate the relative amount of warming occurring in dry air masses, we first stratified the grid cells based upon their average seasonal dew-point temperatures (Fig. 2). Dry grid cells were defined as those with seasonal average dew-point temperatures less than or equal to $0^{\circ} \mathrm{C}$. On an area-weighted basis, dry grid cells accounted for $25.6 \%$ of the area of the available grid cells during the northern hemisphere winter season and $2.2 \%$ during the summer. Due to the rather small number of dry grid cells in the summer, we examined only the cold half-year further. During this period, the average warming trend in the dry grid cells (weighted by area) is $0.214^{\circ} \mathrm{C}$ decade $^{-1}$. This accounts for $78 \%$ of the total hemispheric winter warming. On an areally weighted basis, the change over the remaining $74.4 \%$ of the hemisphere is only $0.021^{\circ} \mathrm{C}$ decade $^{-1}$. Thus the warming rate in cells with mean dew-point temperatures less than $0^{\circ} \mathrm{C}$ is almost 10 times greater than what is observed in cells with dew points above freezing.

A nother implication of our hypotheses is that the intensity of the cold anticyclones should also be positively correlated with the amount of warming. Fig. 3 shows that the locations of the October through $M$ arch average sea-level pressure maxima correspond well to the areas of winter warming in Fig. 1. A regression analysis between temperature change and average pressure across these gridded fields reveals the details 

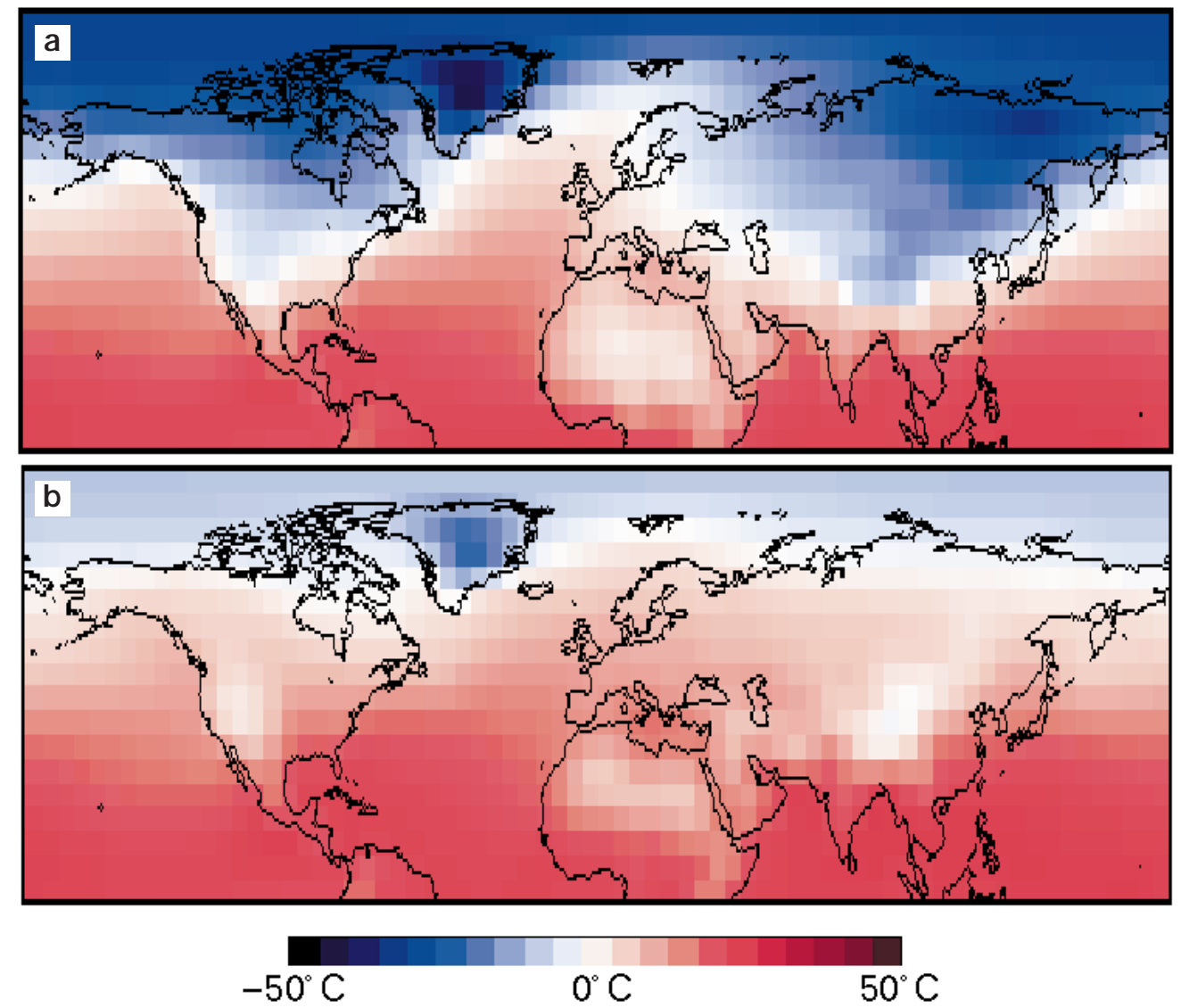

Fig. 2. Mean 1950-1964

(a) winter season (October-M arch) and (b) summer season (April-September) dew-point temperatures $\left({ }^{\circ} \mathrm{C}\right)$
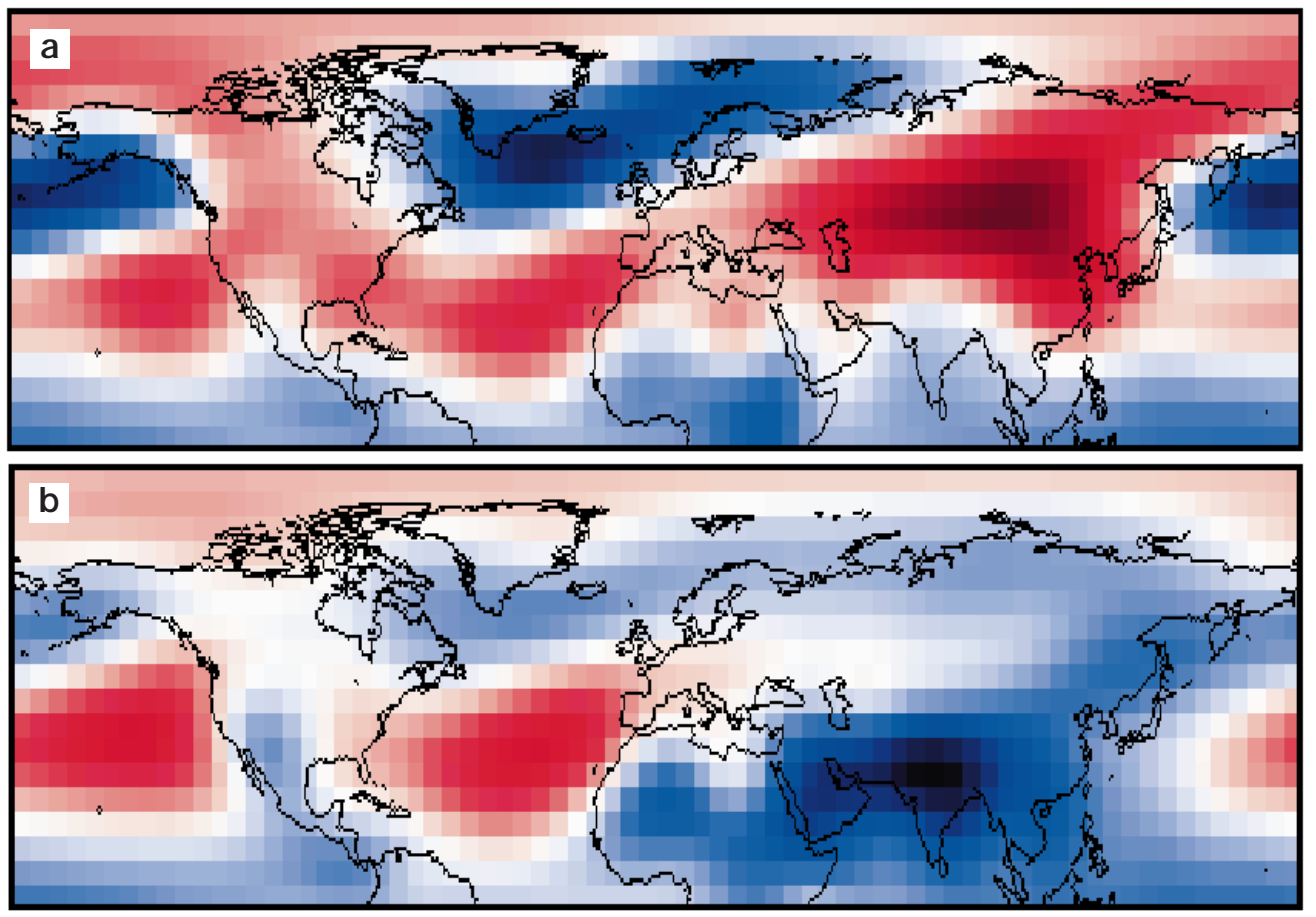

Fig. 3. Mean 1950-1964

(a) winter season (October-M arch) and (b) summer season (April-Sep$1000 \mathrm{hPa}$

$1015 \mathrm{hPa}$ $1030 \mathrm{hPa}$ (hPa) 


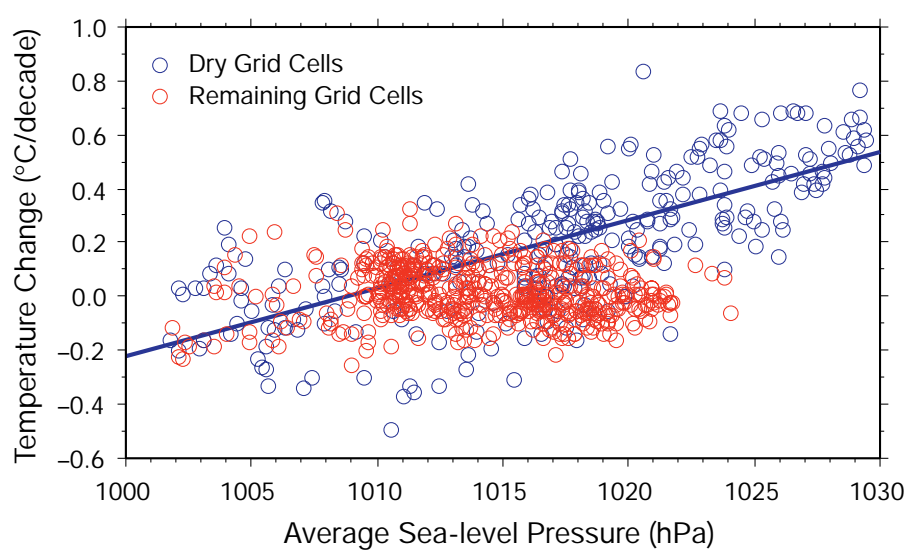

Fig. 4. Relationship between average grid cell pressure and grid cell temperature change for the northern hemisphere winter season. Dry grid cells: grid cells with a seasonal average dew-point temperature less than $0^{\circ} \mathrm{C}$

of this relationship (Fig. 4). The correlation between pressure and warming in the dry grid cells is strong $(r=0.73)$ and highly significant $(p<0.001)$, while there is no statistically significant relationship between warming and pressure in the remaining cells. To determine if spatial autocorrelation reduced the true degrees of freedom in these results, we employed a Monte Carlo approach in which we varied the sample size and estimated the minimum number of grid cells necessary to maintain statistical significance. This analysis verified that the number of grid cells could be reduced 15 -fold and still produce a positive temperature trend/pressure relationship in dry grid cells that is significant at the $p=0.05$ level. Therefore, spatial autocorrelation and overestimation of the true degrees of freedom do not appear to be a significant factor in our results.

\section{DISCUSSION AND CONCLUSION}

Our results indicate that the majority (78\%) of the observed northern hemispheric winter warming during the last $50 \mathrm{yr}$ has been confined to the cold, dry, winter anticyclones. Allowing for the fact that there are virtually no air masses with dew-point temperatures less than $0^{\circ} \mathrm{C}$ in the warm half-year, the effective area of these cold, dry air masses, on an annual basis, is $12.8 \%$ of the total area with adequate data coverage. Scaled for the relative contribution of winter $(69 \%)$ and summer $(31 \%)$ warming to the annual total of $0.051^{\circ} \mathrm{C}$ decade $^{-1}$, only one-eighth of the northern hemispheric area (where there are adequate data) is effectively associated with more than one-half of the observed annual warming.

This result is considerably different than what is generated by most general circulation models (GCMs).
For instance, the Max Planck Institute model, as featured in Chapter Six ('Climate M odels-Projections of Future Climate') of the 1996 IPCC report on climate change, shows that maximum winter warming is predicted to occur north of the core anticyclonic regions in Siberia and North A merica (Houghton et al. 1996, Fig. 6.10, p. 307). A similar pattern of high latitude winter warming is generated by many other current GCMs (e.g. Manabe et al. 1992, Boer 1995, Mitchell \& J ohns 1997). In a recent analysis, Wigley (1999) examined the mean wintertime temperature change across North America forecasted by 15 GCMs and found the greatest warming across northeastern North A merica-an area where the observations show that cooling has occurred during the past $50 \mathrm{yr}$. This lack of correspondence between model results and observations causes one to question the ability of at least some GCMs to reproduce critical features of the climate in the middle- and high-latitude land regions in winter. These mischaracterizations will likely contribute to systematic errors in the forecasts of future warming. A number of reasons could be posited for these systematic errors, including problems in parameterizing interactions between the cryosphere and atmosphere to circulation changes and variations in the residence times of subarctic air masses. Further research is required to explicitly address these possibilities, however.

The fact that observations show that the predominance of the surface warming during the last halfcentury has been confined to very cold and dry air masses needs to be taken into account when considering the overall economic and ecological effects of anthropogenic climate change. Strong warming that is confined mainly to the Siberian and Canadian winter has a much different effect on society than a similarly large heating in mid-latitude urban and agricultural areas during the summer. To us, this pattern of temperature change seems a logical 'discernible human influence' on the climate when the interplay between greenhouse changes and moisture content is considered. Warming of this air mass type may, in fact, be benign or even beneficial, although the final valuation of global warming remains elusive.

\section{LITERATURE CITED}

Balling RC, Michaels PJ , Knappenberger PC (1998) Analysis of winter and summer warming rates in gridded temperature timeseries. Clim Res 9:175-181

Boer GJ (1995) Some dynamical consequences of greenhouse gas warming. Atmos Ocean 33:731-751

Folland CK, Parker DE (1995) Correction of instrumental biases in historical sea surface temperature data. Q J R Meteorol Soc 121:319-367 
Houghton JT, Meira Filho LG, Callander BA, Harris N, Kattenberg A, Maskell K (eds) (1996) Climate change 1995: the science of climate change. Cambridge University Press, Cambridge

J enne RL (1974) J enne's Northern Hemisphere climatology, monthly 1950-1964. National Center for Atmospheric Research dataset ds205.0, NCAR, Boulder, CO (accessed: November 18, 1998); available at: www.scd.ucar.edu/dss/ datasets/ds205.0.html

J ones PD (1994) Hemispheric surface air temperature variations: a reanalysis and an update to 1993. J Clim 7: 1794-1802

J ones PD, Briffa KR, Barnett TP, Tett SFB (1998) High resolution paleoclimatic records for the last millennium: interpretation, integration and comparison with general circulation model control run temperatures. The Holocene 8:455-471

Manabe S, Spleman MJ, Stouffer RJ (1992) Transient responses of a coupled ocean-atmosphere model to gradual changes of atmospheric $\mathrm{CO}_{2}$. Part II: Seasonal response. J Clim 5:105-126

Editorial responsibility: Chris de Freitas, Auckland, New Zealand
Mann ME, Bradley RS, Hughes MK (1999) Northern hemisphere temperature during the past millennium: inferences, uncertainties, and limitations. Geophys Res Lett 26: 759- 762

Mitchell J FB, Johns TC (1997) On modification of global warming by sulfate aerosols. J Clim 10:245-267

Ramanathan V (1981) The role of ocean-atmosphere interactions in the $\mathrm{CO}_{2}$ climate problem. J Atmos Sci 38:918-930

Ramanathan V, Lian MS, Cess RD (1979) Increases atmospheric $\mathrm{CO}_{2}$ : zonal and seasonal estimates of the effect on the radiation energy balance and surface temperature. J Geophys Res 84:4949-4958

Staley DO, J urica GM (1970) Flux emissivity tables for water vapor, carbon dioxide and ozone. J Appl Meteorol 9: 365-372

Staley DO, J urica GM (1972) Effective atmospheric emissivity under clear skies. J Appl Meteorol 11:349-356

Wigley TML (1999) The science of climate change: global and U.S. perspectives. Pew Center on Global Climate Change, Arlington, VA (accessed: August 5, 1999); available at: www.pewclimate.org/projects/env_science.html

Submitted: J une 1, 1999; Accepted: October 18, 1999

Proofs received from author(s): N ovember 30, 1999 